\title{
The Degree of Implementing Hoshin Kanri Methodology in Developing Quality of Culture at the Jordanian Secondary Schools
}

\author{
Alaa Hashim Hetria \\ Mayar International Schools \\ Prof. Dr. Mohammad Saleem Al-Zboun \\ University of Jordan / Faculty of Educational Sciences / Department of Educational Leadership and Foundations
}

\begin{abstract}
The study aimed to identify the degree of implementing Hoshin Kanri methodology in developing the quality of culture at the Jordanian secondary schools. The study sample consisted of (190) female and male secondary school principals. To achieve the study's objectives, a related questionnaire has been used. The results of the study showed that the degree of implementing Hoshin Kanri methodology in developing the quality of culture at the Jordanian secondary schools was moderate from the secondary school principals' point of view. In light of the results, the study recommends developing techniques to effectively advance the Hoshin Kanri implementation levels in Jordanian schools.
\end{abstract}

Key Words: Hoshin Kanri Methodology, Quality of Culture, Secondary Schools, Jordan

DOI: $10.7176 / \mathrm{JEP} / 10-36-21$

Publication date: December $31^{\text {st }} 2019$

\section{Introduction}

The world daily witnesses several contemporary global developments such as technological and cognitive development, which affects over all areas of life, whether economic, social, political, or educational one. This requires all systems - including the educational system - to address and adapt these challenges and work to provide its services and outputs in the required manner, ensuring that it achieves its progress in all fields and in a manner in accordance with the nature of its tasks by using time to achieve its assigned function.

The educational administration is considered one of the most significant elements of the educational process, as it is responsible for implementing educational policies, plans, and programs and translating the objectives into a tangible reality and a living behavior. The administrative leadership is also liable for the proper functioning and direction of the educational process, as it has the responsibility to make decisions to overcome problems, to confront the future efficiently, and to pave the way for expected developments (Al-Baddah and Al-Sarayrah, 2012).

Besides, the process of adopting concepts of quality management is seen as a strategic importance at the level of educational institutions that make educational management live in an era characterized by renewal, and the search for more efficiency and creativity in the educational process, in line with the rapid and successive developments and changes taking place in the era in all sectors. And so, the educational administration finds itself from time to time in front of challenges that compel it to eliminate the previously used principles and methods. Subsequently, the application of modern principles and methods in educational institutions is tremendously essential (Sharon, 2017).

Largely, quality components address programs, curricula, teaching staff, school facilities, administrative processes, student support, and assessment and feedback processes. Considering the educational process as a system, the quality focuses on the inputs, processes, and outputs of the educational system. In details, inputs are represented in programs, curricula, students, teaching staff, school facilities, buildings, and educational technologies. As for operations, it consists of teaching, evaluation, guidance, direction, services, and the student represents the outputs of the educational system (Jawhar, 2017).

Consideration and attention to quality assurance in educational institutions have begun by looking at education as a commodity like other commodities, as educational institutions must compete and seek to satisfy this commodity's consumers who are the students, society, and the state. For example, students want to get the best level of education that qualifies them for excellence and creativity, as well as the students' parents who are looking for the best education to qualify their children. As for the state, it aspires to achieve distinguished 
educational outcomes, enabling it to achieve the objectives of its development plans (Al-Khudair, 2001).

For that reason, several strategies related to the total quality have appeared, including the Hoshin Kanri strategy. The Hoshin Kanri approach has quickly emerged and is constructed on the management through objectives, so that principals can understand the highest objectives by linking the interim objectives and the institution's strategic objectives. This planning-related approach used in Japanese organizations is considered one of the effective methodologies in strategic quality management because of its benefits outweigh the benefits of the traditional planning techniques. Among these benefits are integrating of strategic objectives with daily planning management, applying of the planning cycle to the management process, making a parallel methodology for planning and implementation, improving communications, and creating a growing opinion consensus in setting goals. As for the elements included in the methodology, they are a vision of the next five years, an annual plan, spreading objectives, a detailed implementation, and analysis (Witcher, 2014).

Of note, the Hoshin administration is based on a set of basic principles, namely: aligning the organization's objectives with changes in the external environment, focusing on addressing critical strategic gaps, participating of all administrative and executive levels in developing plans to end the gaps, defining methods and criteria for measuring the achievement of strategic objectives, linking the long-term strategic plan to the short-term interim plans, and modifying the plans continuously based on feedback from the lower administrative and executive levels (Ahmad, 2016).

The origin of the Hoshin Kanri methodology dates back to the mid-1950s. Though the exact date of the introduction of this methodology is not yet clear, little administrative literature indicates that the concept of this methodology has begun in parallel with the introduction of the concept of quality control adopted by the Japan Science and Technology Agency (JST). Furthermore, there were some indications that the basis for developing this methodology is constructed by mixing Edward Deming's ideas and ideologies in the processes that institutions in Japan have been performing with Peter Druckers' philosophy of management with objectives. This provides indications that there is a close relationship between Total Quality Management (TQM) and the Hoshin Kanri’s methodology (Melander, Lofving, Andersson, Elgh, \& Thulin, 2016).

Osada (1998) defined the methodology of Hoshin Kanri of the Total Quality Management (TQM) as it is the process of selecting strategic change, which in many institutions, is called strategic planning. This process begins when the organization works to determine the proposed changes in order to increase the competitive performance of one of its operations, or to find a competitive attraction for the product that it offers in its active market. In these two processes, strategic choices are essential in order to apply the concept of a competitive enterprise. Many companies and institutions in Western countries have focused their attention on addressing the key aspects of formulating the strategy that governs operations, as strategies able to achieve the desired objectives stated in the policy of the institution have been wisely selected.

Nicholas (2014) stated that the methodology of the Hoshin Kanri is a common model used in Japanese institutions, though its use is limited in institutions of Western countries. Also, western institutions that adopt this methodology are usually huge institutions. Besides, the application of this methodology was not the focus of studies and research in Management Science, although it provides an effective tool in increasing the level of organizational processes at the adequacy of levels and makes a fundamental change to the organizational culture in the organization, which reflects positively on raising the quality of operations.

In fact, few studies have examined the quality management and the Hoshin Kanri methodology. The study of Alic and Ideskog (2016) in Sweden aimed to research the Hoshin Kanri theory, provide a framework about it, present some management practices based on this methodology. The study sample consisted of (14) Japanese companies working in Sweden in which the principals answered interview questions made by phone. To achieve the aim of the study, content analysis was used. The results showed that structuring Hoshin Kanri methodology in companies can take a serial method based on a set of clear steps or a set of cyclic steps. The results also showed that clarifying the basic elements of the Hoshin Kanri methodology motivates companies to use them as an effective way to increase quality confidence.

In their study conducted in Algeria, Souad, Messaouda, \& Maazouzi (2017) aimed at developing a model based on the Hoshin Kanri methodology and applying it in companies. The study used the critical and descriptive methodology based on reviewing the previous relevant literature. The content of (11) previous studies addressing the use of the Hoshin Kanri methodology has been analyzed. The results revealed that the Hoshin Kanri methodology provides an effective tool in clarifying the strategic vision of the institution, as it works to find complementarity between the set of organizational goals within a comprehensive organizational model based on 
a set of effective administrative processes. The results showed that the Hoshin Kanri methodology is an effective method for strategic planning, which positively affects administrative processes, as it provides a comprehensive methodology for integrating strategic goals into routine administrative practices, applying the concept (Plan, Implement, and Evaluate (PIE) for the performance of administrative operations.

In his study conducted in the Philippines, Avila (2018) aimed to identify the relationship between school management practice of quality management and its impact on teachers' performance. The sample of the study consisted of (132) male and female teachers and (37) principals from the public and private schools in Quezon Province. To achieve the aim of the study, a Quality Management Scale and personal interviews were used. The results of the study indicated that the level of school principals' application of quality culture was of an moderate degree. The results of the study showed that there are statistically significant differences in the level of school principals' application of quality management in schools due to the variable of study type, and in favor of private schools. The results showed that the application of school principals to quality management contributes to reducing school dropout.

In their study, Dziminska, Fijallkowska, \& Sulzowski (2018) aimed at developing a model for higher education institutions based on a culture of quality. To achieve the objective of the study, the literature and previous studies dealing with the topic of quality culture has been reviewed. The results of the study showed that the proposed model contributes to enhancing concepts related to organizational culture, such as loyalty, trust, and organizational reputation. The results indicated that the proposed model may contribute to the decision-making process. The results revealed that the proposed model is between the need for higher education institutions to enjoy a level of transparency and clarity, and reliable administrative systems based on the development of their quality culture.

Through research and knowledge, it was found that previous studies dealt with the issue of quality culture in several aspects. Yet, they did not address the dissemination of quality culture based on the methodology of Hoshin Kanri directly.

\section{Problem and Question of the Study}

Certain studies have shown that educational institutions, including schools, are required to achieve a culture of quality after the sharp criticisms aginst schools in light of the low level at the global level because of the absence of effective strategic visions, the lack of strategic planning, and the absence of the necessary vision and organizational culture to support its orientation towards globalization.

Moreover, the problem of study is seen through the experience of a researcher as a female manager of a private school and her participation in many meetings and seminars related to the quality of education in Jordan. Based on these seminars, it has been found that there is a decline in education outcomes compared to the level of schools in the world according to international tests in a number of academic subjects in which students obtained low results such as Tims and Pisa tests, which requires a review of the structure of education in schools to be able to provide a clear and distinct message and vision about education according to the quality culture that works to develop educational institutions and society. with that, the problem of the study arises by trying to answer the following question "What is the degree of high school implementation of the Hoshin Kanri methodology in achieving a culture of quality in it from its principals' standpoint?"

\section{Significane of the Study}

The significance of the study appears in theory and in practice. The theoretical significance of the study is the importance of the information attained by referring to the previous literature. According to the researchers, these studies are among the first studies to discuss the role of secondary schools in developing a culture of quality based on the Hoshin Kanri methodology, which has not beed tackled by any previous study which constitutes a new add to the Arab Library.

In terms of application, its significance is seen through the benefit it provides to the Ministry of Education such as issuing brochures to develop a culture of quality in schools, conducting awareness sessions for male and female teachers, inking professional development to the extent of application of quality and its principles, and activating principals and teachers through holding courses, training programs, and workshops and attending educational conferences for quality management. 


\section{Methodology of the Study}

To achieve the aims of the study, the descriptive analytical survey method was used.

\section{The Study Population and Sample}

The study population consisted of all 1136 male and female principals of secondary schools for the academic year (2019/2020) according to the statistics of the Ministry of Education in 2019. A random stratified sample consisting of (190) male and female principals has been select from the total study population.

\section{Study Instrument}

To achieve the aims of the study, a questionnaire was developed to address the culture of quality by referring to theoretical literature and previous studies such as Ashtel's study (2018) and other related studies.

\section{Validity of the Study Instrument}

To verify the validity of the instrument, validity of the content was used by presenting it to a group of experts and specialists in a number of Jordanian universities, and the Ministry of Education with the aim of expressing their views on the questionnaire items in terms of clarity of meaning, linguistic formulation, the degree of suitability for the field to which it belongs, and any other appropriate amendments and notes. Later on, $(80 \%)$ of the observations of the raters were taken in order to achieve the objectives of the study without neglecting to make the proposed amendments related to the language formulation of the items.

\section{Indicators of the Construct Validity}

To extract the significance of construct validity for the scale, the two researchers extracted correlation coefficients of items of the scale with the total score through an exploratory sample from the study population and from outside its 20 male and female principal sample, where the items of the scale were analyzed and the correlation coefficient of each of the item was calculated. The correlation coefficient represents an indicator of validity for each item in the form of a correlation coefficient between each item and the total degree of the coefficient to which it belongs from one side. In more details, the correlation coefficients between the item and the total degree of the dimension to which it belongs have ranged between $(0.30-0.82)$, and therefore all correlation coefficients have statistically acceptable and significant degrees.

\section{Reliability of the Study Instrument}

The reliability of the study instrument was verified by using the application and re-application (test-retest), as the instrument was applied to (20) male and female principals from the study population and from outside its sample, and re-applied on them after two weeks. Then, the consistency coefficient was calculated using the Pearson's Correlation Coefficient between the results of the two applications. Internal consistency coefficients were also extracted using the Cronbach-Alpha Equation. Table (1) shows the internal consistency coefficient according to the Cronbach-Alpha Equation and the reliability of the return of the coefficients. These values were considered appropriate for the purposes of this study. 
Table (1): The Internal Consistency Coefficient of the Cronbach Alpha and the Reliability of Return of the Dimensions of the Quality Culture Scale

\begin{tabular}{|l|l|l|}
\hline Dimension & Reliability of the Return & Internal Consistency Coefficient \\
\hline Analysis before plan development & 0.90 & 0.71 \\
\hline Task development & 0.96 & 0.87 \\
\hline Value added development & 0.89 & 0.87 \\
\hline Vision development & 0.93 & 0.85 \\
\hline $\begin{array}{l}\text { Preparing long and short term } \\
\text { goals }\end{array}$ & 0.85 & 0.83 \\
\hline Making annual plans & 0.91 & 0.89 \\
\hline $\begin{array}{l}\text { Spreading a culture of quality of } \\
\text { service }\end{array}$ & 0.94 & 0.91 \\
\hline Application at the teacher level & 0.87 & 0.84 \\
\hline Calendar & 0.88 & 0.85 \\
\hline Standard setting & 0.90 & 0.85 \\
\hline Setting goals & 0.94 & 0.90 \\
\hline $\begin{array}{l}\text { Feedback between the principal } \\
\text { and the teachers }\end{array}$ & 0.86 & 0.80 \\
\hline Challenges and difficulties & 0.91 & 0.89 \\
\hline
\end{tabular}

Table (1) indicates that the values of the internal consistency coefficient for the dimensions of the quality culture scale ranged between (0.71-0.91), while the values of reliability of return for the dimensions of the quality culture scale ranged between (0.85-0.96), which indicates that the values of the validity and reliability coefficients for the scale were acceptable.

\subsection{Statistical Standard (SS)}

The five-level Likert scale was adopted to correct the study instruments by giving each of its items one of the five grades (Strongly disagree, Disagree, Neither agree nor disagree, Agree, Strongly agree), represented digitally $(5,4,3,2,1)$, respectively, The following scale has been adopted for the purposes of analyzing the results:

From $1.00-2.33$ is few

$3.67-2.34$ is medium

From 3.68-5.00 is great

And so on

The scale was calculated using the following formula:

Upper limit for scale (5) - Lower limit for scale (1)

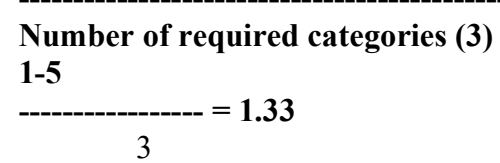

Then add the answer (1.33) to the end of each category.

9.. Results and Discussion of the Study

Results of the study question: "What is the degree of high school implementation of the Hoshin Kanri methodology in achieving a culture of quality in it from its principals' standpoint?"

To answer this question, the mean and standard deviations were calculated to the degree of high school's implementations of Hoshin Kanri's methodology in achieving a culture of in it from its principals' standpoint, and the table below shows that. 
Table (2): Arithmetical means and standard deviations for the degree of secondary schools' implementation of Hoshin Kanri methodology in achieving a culture of quality in it from its principals' standpoint in descending order according to arithmetical means

\begin{tabular}{|c|c|c|c|c|c|}
\hline Rank & No & $\overline{\text { Area }}$ & $\begin{array}{l}\text { Arithmetical } \\
\text { mean }\end{array}$ & $\begin{array}{l}\text { Standard } \\
\text { deviation }\end{array}$ & Level \\
\hline 1 & 13 & Challenges and difficulties & 3.44 & .819 & Medium \\
\hline 2 & 10 & Standard setting & 3.07 & .897 & Medium \\
\hline 3 & 5 & Preparing long and short term goals & 3.06 & .826 & Medium \\
\hline 4 & 4 & Vision development & 3.04 & .904 & Medium \\
\hline 5 & 2 & Task development & 3.01 & .781 & Medium \\
\hline 6 & 7 & $\begin{array}{l}\text { Spreading a culture of quality of } \\
\text { service }\end{array}$ & 2.99 & .845 & Medium \\
\hline 7 & 12 & $\begin{array}{l}\text { Feedback between principal and } \\
\text { teachers }\end{array}$ & 2.96 & .901 & Medium \\
\hline 8 & 9 & Calendar & 2.95 & .844 & Medium \\
\hline 9 & 3 & Value added development & 2.90 & .933 & Medium \\
\hline 10 & 8 & Application at teacher level & 2.89 & .788 & Medium \\
\hline 11 & 6 & Making annual plans & 2.80 & .984 & Medium \\
\hline 12 & 1 & Analysis before plan development. & 2.74 & .691 & Medium \\
\hline 13 & 11 & Setting goals & 2.61 & .877 & Medium \\
\hline & & The instrument as a whole & 2.97 & .598 & Medium \\
\hline
\end{tabular}

Table (2) shows that the arithmetic averages ranged (2.61-3.44), where the challenges and difficulties came in the first rank with the highest arithmetic mean of (3.44), while setting the goals came in the last rank with an arithmetic mean of (2.61). The arithmetic mean of the instrument as a whole was (2.97). The arithmetic means and standard deviations for the study sample's member's estimates were calculated on the items of each field separately as follows:

The First Area: Analysis before Plan Development

Table (3): The arithmetic means and the standard deviations of the items related to the Analysis before Plan Development in descending order according to the arithmetic means

\begin{tabular}{|c|c|c|c|c|c|}
\hline Rank & No & Area & $\begin{array}{l}\text { Arithmetical } \\
\text { mean }\end{array}$ & $\begin{array}{l}\text { Standard } \\
\text { deviation }\end{array}$ & Level \\
\hline 1 & 6 & $\begin{array}{l}\text { The available organizational data is } \\
\text { analyzed to develop strategic plans. }\end{array}$ & 2.87 & .940 & Medium \\
\hline 2 & 5 & $\begin{array}{l}\text { School administration uses } \\
\text { community organizations to improve } \\
\text { the quality of education provided. }\end{array}$ & 2.85 & .954 & Medium \\
\hline 3 & 3 & $\begin{array}{l}\text { School administration engages } \\
\text { teachers in developing its plan. }\end{array}$ & 2.76 & .819 & Medium \\
\hline 4 & 4 & $\begin{array}{l}\text { School administration engages } \\
\text { teachers and parents in developing } \\
\text { future visions. }\end{array}$ & 2.73 & .907 & Medium \\
\hline 5 & 1 & $\begin{array}{l}\text { School administration provides } \\
\text { appropriate educational services. }\end{array}$ & 2.67 & 1.132 & Medium \\
\hline \multirow[t]{2}{*}{6} & 2 & $\begin{array}{l}\text { Parents participate } \\
\text { development of the } \\
\text { program. }\end{array}$ & 2.58 & .880 & Medium \\
\hline & & Analysis before plan development & 2.74 & .691 & Medium \\
\hline
\end{tabular}


Table (3) shows that the arithmetic means between (2.58-2.87), as item (6) states that "The available organizational data is analyzed to develop strategic plans" came in the first place with an arithmetic mean of (2.87), while item (2) which states," Parents participate in the development of the scholastic program." came in the last rank with an average of (2.58). The athematic mean of the Analysis before Plan Development as a whole was (2.74).

\section{The Second Area: Task Development}

Table (4): The arithmetic means and the standard deviations of the items related to the task development in descending order according to the arithmetic means.

\begin{tabular}{|c|c|c|c|c|c|}
\hline Rank & No & Area & $\begin{array}{l}\text { Arithmetical } \\
\text { mean }\end{array}$ & $\begin{array}{l}\text { Standard } \\
\text { deviation }\end{array}$ & Level \\
\hline 1 & 11 & $\begin{array}{l}\text { School administration works to spread } \\
\text { an educational philosophy based on the } \\
\text { fact that students are at the center of the } \\
\text { educational process. }\end{array}$ & 3.19 & 1.069 & Medium \\
\hline 2 & 10 & $\begin{array}{l}\text { School administration works to develop a } \\
\text { task related to the quality of education } \\
\text { provided to students. }\end{array}$ & 3.04 & .945 & Medium \\
\hline 3 & 9 & $\begin{array}{l}\text { School administration works on } \\
\text { embodying the educational values } \\
\text { referred to in educational philosophy. }\end{array}$ & 2.98 & .940 & Medium \\
\hline 4 & 8 & $\begin{array}{l}\text { School administration actively } \\
\text { communicates with (teachers and } \\
\text { workers) to clarify its goals. }\end{array}$ & 2.96 & .959 & Medium \\
\hline 5 & 7 & $\begin{array}{l}\text { School administration uses the channels } \\
\text { (internal and external) to inform the } \\
\text { officials of the quality of the education } \\
\text { provided. }\end{array}$ & 2.90 & .951 & Medium \\
\hline & & Task development & 3.01 & .781 & Medium \\
\hline
\end{tabular}

Table (4) shows that the arithmetic means ranged (3.19-2.90), as item (11) states that "The school administration works to spread an educational philosophy based on the fact that students are at the center of the educational process" came in the first place with a mean of (3.19), while item (7) stated, "The school administration uses the channels (internal and external) to inform the officials of the quality of the education provided" came in the last rank with a mean of (2.90). The arithmetic mean for the Task Development as a whole was (3.01).

The Third Area: Value added development

Table (5): The arithmetic means and the standard deviations of the items related to the value added development in descending order according to the arithmetic means

\begin{tabular}{|c|c|c|c|c|c|}
\hline Rank & No & Area & $\begin{array}{l}\text { Arithmetical } \\
\text { mean }\end{array}$ & $\begin{array}{l}\text { Standard } \\
\text { deviation }\end{array}$ & Level \\
\hline 1 & 12 & $\begin{array}{l}\text { School administration is concerned with } \\
\text { student's academic outputs }\end{array}$ & 3.22 & .983 & Medium \\
\hline 2 & 14 & $\begin{array}{l}\text { School administration sets the } \\
\text { foundations for behavioral discipline in } \\
\text { line with the school's goals and mission }\end{array}$ & 2.88 & .993 & Medium \\
\hline 3 & 13 & $\begin{array}{l}\text { School administration directs the } \\
\text { activities of teachers and workers } \\
\text { towards improving the quality of } \\
\text { education provided }\end{array}$ & 2.61 & 1.224 & Medium \\
\hline & & Value added development & 2.90 & .933 & Medium \\
\hline
\end{tabular}

Table (5) shows that the arithmetic means ranged (2.61-3.22), as item (12) states that "School administration is concerned with student's academic outputs" came in the first place with an arithmetic mean of (3.22), while item (13) states, " The school administration directs the activities of teachers and workers towards improving the 
quality of education provided" came in the last rank with a mean of (2.61). The arithmetic mean for Value Added Development as a whole was (2.90).

\section{The Fourth Area: Vision Development}

Table (6): The arithmetic means and the standard deviations of the items related to Vision Development in descending order according to the arithmetic means

\begin{tabular}{|c|c|c|c|c|c|}
\hline Rank & & Area & $\begin{array}{l}\text { Arithmetical } \\
\text { mean }\end{array}$ & $\begin{array}{l}\text { Standard } \\
\text { deviation }\end{array}$ & Level \\
\hline 1 & 20 & $\begin{array}{l}\text { School administration vision aims to find } \\
\text { effective communication channels with } \\
\text { all levels of administration in it. }\end{array}$ & 3.14 & 1.040 & Medium \\
\hline 2 & 18 & $\begin{array}{l}\text { School's vision is to provide the highest } \\
\text { quality education possible for students. }\end{array}$ & 3.10 & 1.047 & Medium \\
\hline 3 & 19 & $\begin{array}{l}\text { School administration's message seeks to } \\
\text { provide a supportive organizational } \\
\text { environment for teachers and workers. }\end{array}$ & 3.03 & 1.031 & Medium \\
\hline 4 & 16 & School's vision outlines its aspirations. & 3.01 & 1.091 & Medium \\
\hline 5 & 17 & $\begin{array}{l}\text { School's vision determines its future } \\
\text { directions. }\end{array}$ & 3.01 & 1.091 & Medium \\
\hline \multirow[t]{2}{*}{6} & 15 & $\begin{array}{l}\text { School administration embodies its vision } \\
\text { of what it seeks to achieve through its } \\
\text { various activities }\end{array}$ & 2.95 & 1.048 & Medium \\
\hline & & Vision development & 3.04 & .904 & Medium \\
\hline
\end{tabular}

Table (6) shows that the arithmetic means ranged (2.95 - 3.14), as item (20) states that "The school administration vision aims to find effective communication channels with all levels of administration in it" came in the first rank with an arithmetic mean of (3.14), while item (15), which states "The school administration embodies its vision of what it seeks to achieve through its various activities," came in the last rank with a mean of (2.95). The arithmetical mean for Vision Development as a whole was 3.04 .

The Fifth Area: Preparing Long and Short Term Goals

Table (7): The arithmetic means and the standard deviations of the items related to Preparing Long and Short Term Goals in descending order according to the arithmetic means

\begin{tabular}{|c|c|c|c|c|c|}
\hline Rank & & Area & $\begin{array}{l}\text { Arithmetical } \\
\text { mean }\end{array}$ & $\begin{array}{l}\text { Standard } \\
\text { deviation }\end{array}$ & Level \\
\hline 1 & 22 & $\begin{array}{l}\text { School administration outlines its short } \\
\text { and long term goals in its message to } \\
\text { achieve the vision. }\end{array}$ & 3.19 & .968 & Medium \\
\hline 2 & 23 & $\begin{array}{l}\text { School administration provides a } \\
\text { supportive learning environment to } \\
\text { encourage students to learn. }\end{array}$ & 3.18 & 1.064 & Medium \\
\hline 3 & 24 & $\begin{array}{l}\text { School administration communicates } \\
\text { with parents to define the short and long } \\
\text { term goals they seek to achieve. }\end{array}$ & 2.94 & 1.060 & Medium \\
\hline 4 & 21 & $\begin{array}{l}\text { School administration conducts an } \\
\text { analysis of the elements of the } \\
\text { surrounding environment to discover the } \\
\text { points (strengths and weaknesses) in it. }\end{array}$ & 2.91 & .932 & Medium \\
\hline & & Preparing long and short term goals & 3.06 & .826 & Medium \\
\hline
\end{tabular}

The sixth Area: Making Annual Plans 
Table (8): The arithmetic means and the standard deviations of the items related to Making Annual Plans in descending order according to the arithmetic means

\begin{tabular}{|l|l|l|l|l|l|}
\hline Rank & No & Area & Arithmetical mean & $\begin{array}{l}\text { Standard } \\
\text { deviation }\end{array}$ \\
\hline 1 & 29 & $\begin{array}{l}\text { The appropriate means and strategies } \\
\text { are selected to achieve the desired } \\
\text { outcomes. }\end{array}$ & 2.91 & 1.038 \\
\hline 2 & 28 & $\begin{array}{l}\text { A clear deadline is set to assess the } \\
\text { schools ability to achieve its goals. }\end{array}$ & $\mathbf{2 . 8 7}$ & $\mathbf{1 . 0 9 6}$ \\
\hline 3 & 27 & $\begin{array}{l}\text { School administration is developing } \\
\text { effective tools to measure its outputs at } \\
\text { the end of the school year. }\end{array}$ & $\mathbf{1 . 1 5 7}$ & Medium \\
\hline 4 & 26 & $\begin{array}{l}\text { School administration develops } \\
\text { evaluation methods to achieve school } \\
\text { goals through performance indicators. }\end{array}$ & $\mathbf{2 . 7 3}$ & $\mathbf{1 . 0 0 2}$ \\
\hline 5 & $\mathbf{2 5}$ & $\begin{array}{l}\text { The annual plan outlines desired } \\
\text { outputs through the work of the school. }\end{array}$ & $\mathbf{2 . 7 2}$ & $\mathbf{2 . 4 6 7}$ \\
\hline
\end{tabular}

Table (8) shows that the arithmetic means ranged (2.72-2.91), as item (29) stated that " The appropriate means and strategies are selected to achieve the desired outcomes" came in the first rank with an arithmetic mean of (2.91), while item (25) states that "The annual plan outlines desired outputs through the work of the school", came in the last rank with a mean of (2.72). The arithmetical mean for Making Annual Plans as a whole was (2.80).

The Seventh Area: Spreading a Culture of Quality of Service

Table (9): The arithmetic means and the standard deviations of the items related to Spreading a Culture of Quality of Service in descending order according to the arithmetic means

\begin{tabular}{|c|c|c|c|c|c|}
\hline Rank & No & Area & Arithmetical mean & $\begin{array}{l}\text { Standard } \\
\text { deviation }\end{array}$ & Level \\
\hline 1 & 33 & $\begin{array}{l}\text { School administration works to find a } \\
\text { balance between the competencies and } \\
\text { skills of teachers and workers, and the } \\
\text { educational outcomes that the school } \\
\text { seeks to achieve. }\end{array}$ & 3.04 & 1.023 & Medium \\
\hline 2 & 31 & $\begin{array}{l}\text { School administration sets up a set of } \\
\text { substitutes that can help in achieving } \\
\text { the highest levels of education quality. }\end{array}$ & 3.03 & 1.051 & Medium \\
\hline 3 & 34 & $\begin{array}{l}\text { A group of teachers and workers who } \\
\text { are able to embody the strategy on the } \\
\text { ground is selected. }\end{array}$ & 3.02 & 1.091 & Medium \\
\hline 4 & 32 & $\begin{array}{l}\text { An effective and able strategy is } \\
\text { selected to help the school } \\
\text { administration in raising the quality of } \\
\text { the education provided. }\end{array}$ & 2.95 & .996 & Medium \\
\hline \multirow[t]{2}{*}{5} & 30 & $\begin{array}{l}\text { The tasks of teachers and workers are } \\
\text { clearly defined in improving the } \\
\text { quality of education provided. }\end{array}$ & 2.91 & 1.053 & Medium \\
\hline & & $\begin{array}{l}\text { Spreading a Culture of Quality of } \\
\text { Service }\end{array}$ & 2.99 & .845 & Medium \\
\hline
\end{tabular}

Table (9) shows that the arithmetic means ranged (2.91-3.04), as stated in item (33), which states "The school administration works to find a balance between the competencies and skills of teachers and workers, and the educational outcomes that the school seeks to achieve" came in the first rank with a mean of (3.04), while item (30) which states" The tasks of teachers and workers are clearly defined in improving the quality of education 
provided" came in the last rank with a mean of (2.91). The arithmetic mean of Spreading a Culture of Quality of Service as a whole was (2.99).

The Eighth Area: Application at the Teacher Level

Table (10): The arithmetic means and the standard deviations of the items related to Application at the Teacher Level in descending order according to the arithmetic means

\begin{tabular}{|c|c|c|c|c|c|}
\hline Rank & No & Area & Arithmetical mean & Standard deviation & Level \\
\hline 1 & 36 & $\begin{array}{l}\text { School administration encourages the } \\
\text { application of the principles of strategic } \\
\text { planning }\end{array}$ & 3.18 & 1.093 & Medium \\
\hline 2 & 41 & $\begin{array}{l}\text { All teachers and workers are involved in } \\
\text { providing their opinions on improving the } \\
\text { quality of education provided in the school. }\end{array}$ & 2.97 & 1.018 & Medium \\
\hline 3 & 35 & $\begin{array}{l}\text { A set of systems is developed based on a set } \\
\text { of performance indicators. }\end{array}$ & 2.96 & .922 & Medium \\
\hline 4 & 40 & $\begin{array}{l}\text { School administration spreads a culture of } \\
\text { quality to achieve the desired goals in the } \\
\text { hearts of teachers and workers in the school. }\end{array}$ & 2.93 & 1.091 & Medium \\
\hline 5 & 39 & $\begin{array}{l}\text { School administration communicates with } \\
\text { teachers to encourage them to reach the } \\
\text { highest levels of education quality. }\end{array}$ & 2.85 & 1.064 & Medium \\
\hline 6 & 38 & $\begin{array}{l}\text { School administration works to spread the } \\
\text { spirit of initiative among teachers to } \\
\text { implement the indicators of education } \\
\text { quality. }\end{array}$ & 2.82 & 1.004 & Medium \\
\hline 7 & 37 & $\begin{array}{l}\text { School administration works to encourage } \\
\text { teachers to apply the principles of strategic } \\
\text { planning. }\end{array}$ & 2.51 & 1.032 & Medium \\
\hline & & Application at teacher level & 2.89 & .788 & Medium \\
\hline
\end{tabular}

Table (10) shows that the arithmetic means ranged between (2.51-3.18), as item (36) states that" School administration encourages the application of the principles of strategic planning" came in the first place with an arithmetic mean of (3.18), while the item (37) which states "School administration works to encourage teachers to apply the principles of strategic planning", came in the last rank with an arithmetic mean of (2.51). The arithmetic mean of the Application at the Level of Teachers as a whole is (2.89).

\section{The Ninth Area: Calendar}

Table (11): The arithmetic means and the standard deviations of the items related to Calendar in descending order according to the arithmetic means

\begin{tabular}{|c|c|c|c|c|c|}
\hline$\overline{\text { Rank }}$ & No & Area & $\begin{array}{l}\text { Arithmetical } \\
\text { mean }\end{array}$ & $\begin{array}{l}\text { Standard } \\
\text { deviation }\end{array}$ & Level \\
\hline 1 & 44 & $\begin{array}{l}\text { Comprehensive reviews are } \\
\text { provided on the plans used in the } \\
\text { implementation process. }\end{array}$ & 2.98 & .997 & Medium \\
\hline 2 & 42 & $\begin{array}{l}\text { The work is done to identify the } \\
\text { problems faced by teachers and } \\
\text { workers during the application } \\
\text { process. }\end{array}$ & 2.96 & .975 & Medium \\
\hline 3 & 43 & $\begin{array}{l}\text { School administration develops } \\
\text { corrective mechanisms to overcome } \\
\text { problems. }\end{array}$ & 2.96 & 1.002 & Medium \\
\hline \multirow[t]{2}{*}{4} & 45 & $\begin{array}{l}\text { Specialized institutions are used to } \\
\text { evaluate the application process. }\end{array}$ & 2.92 & 1.131 & Medium \\
\hline & & Calendar & 2.95 & .844 & Medium \\
\hline
\end{tabular}


Table (11) shows that the arithmetic means ranged (2.92-2.98), as item (44) states that "Comprehensive reviews are provided on the plans used in the implementation process", came in the first place with a mean of (2.98), while item (45) which states" Specialized institutions are used to evaluate the application process", came in the last rank with a mean of (2.92). The arithmetic mean for the Calendar as a whole was (2.95).

\section{The Tenth Area: Standard Setting}

Table (12): The arithmetic means and the standard deviations of the items related to Standard Setting in descending order according to the arithmetic means

\begin{tabular}{|l|l|l|l|l|l|}
\hline Rank & No & Area & $\begin{array}{l}\text { Arithmetical } \\
\text { mean }\end{array}$ & $\begin{array}{l}\text { Standard } \\
\text { deviation }\end{array}$ & Level \\
\hline 1 & 48 & $\begin{array}{l}\text { School administration works to } \\
\text { improve daily operations on the } \\
\text { school day by applying a set of } \\
\text { standards. }\end{array}$ & 1.150 & Medium \\
\hline 2 & 47 & $\begin{array}{l}\text { The opinions of educational experts } \\
\text { are used to set standards that can } \\
\text { be achieved in the future. }\end{array}$ & $\begin{array}{l}\text { T.07 } \\
\text { to set future standards. }\end{array}$ & .987 & Medium \\
\hline 3 & 46 & Standard Setting & $\mathbf{9 7 3}$ & Medium \\
\hline
\end{tabular}

Table (12) shows that the arithmetic means ranged (2.98-3.16), as item (48) states that "School administration works to improve daily operations on the school day by applying a set of standards" came in the first place and with an arithmetic mean of (3.16), while item (46) which states, "The application experience is used to set future standards" came in the last rank with a mean of (2.98). The erythematic mean for the Standard Setting as a whole was (3.07).

\section{The Eleventh Area: Setting Goals}

Table (13): The arithmetic means and the standard deviations of the items related to Setting Goals in descending order according to the arithmetic means

\begin{tabular}{|c|c|c|c|c|c|}
\hline$\overline{\text { Rank }}$ & No & Area & $\begin{array}{l}\text { Arithmetical } \\
\text { mean }\end{array}$ & $\begin{array}{l}\text { Standard } \\
\text { deviation }\end{array}$ & Level \\
\hline 1 & 51 & $\begin{array}{l}\text { Teachers participate with school } \\
\text { administration in arranging goals } \\
\text { according to their importance and } \\
\text { priorities. }\end{array}$ & 2.79 & 1.007 & Medium \\
\hline 2 & 50 & $\begin{array}{l}\text { The teachers participate with the } \\
\text { school administration in } \\
\text { determining the activities }\end{array}$ & 2.68 & .995 & Medium \\
\hline \multirow[t]{2}{*}{3} & 49 & $\begin{array}{l}\text { Teachers and administration } \\
\text { participate in setting the school's } \\
\text { goals, each according to their } \\
\text { specialization. }\end{array}$ & 2.37 & .998 & Medium \\
\hline & & Setting Goals & 2.61 & .877 & Medium \\
\hline
\end{tabular}

Table (13) shows that the arithmetic means ranged (2.37-2.79), where item (51) states that "Teachers participate with school administration in arranging goals according to their importance and priorities", came in the first rank with an arithmetic mean of (2.79), while item (49), which states "Teachers and administration participate in setting the school's goals, each according to their specialization", came in the last ranked with a 
mean of (2.37). The arithmetic mean for Setting Goals as a whole was (2.61).

The Twelfth Area: Feedback between Principal and Teachers

Table (14): The arithmetic means and the standard deviations of the items related to Feedback between Principal and Teachers in descending order according to the arithmetic means

\begin{tabular}{|c|c|c|c|c|c|}
\hline Rank & No & Area & Arithmetical mean & $\begin{array}{l}\text { Standard } \\
\text { deviation }\end{array}$ & Level \\
\hline 1 & 56 & $\begin{array}{l}\text { Feedback allows revealing of strengths } \\
\text { and weaknesses in functionality. }\end{array}$ & 3.20 & 1.085 & Medium \\
\hline 2 & 55 & $\begin{array}{l}\text { The school's adopted feedback process } \\
\text { motivates teachers. }\end{array}$ & 3.01 & 1.036 & Medium \\
\hline 3 & 54 & $\begin{array}{l}\text { The feedback process should improve } \\
\text { the level of teacher performance. }\end{array}$ & 2.97 & 1.018 & Medium \\
\hline 4 & 52 & $\begin{array}{l}\text { The principal informs the teachers of } \\
\text { the results of their job evaluation. }\end{array}$ & 2.81 & 1.067 & Medium \\
\hline 5 & 53 & $\begin{array}{l}\text { Feedback is provided immediately } \\
\text { after the evaluation process without } \\
\text { delay. }\end{array}$ & 2.80 & 1.088 & Medium \\
\hline & & $\begin{array}{l}\text { Feedback between } \\
\text { Teachers }\end{array}$ & 2.96 & .901 & Medium \\
\hline
\end{tabular}

Table (14) shows that the arithmetic means ranged (3.20-2.80), as item (56) states that" Feedback allows revealing of strengths and weaknesses in functionality", came in the first rank with a mean of (3.20), while item (53) which states, "Feedback is provided immediately after the evaluation process without delay", came in the last rank with a mean of (2.80). The mean arithmetic for Feedback between the Principal and Teachers as a whole was (2.96).

The Thirteenth Area: Challenges and Difficulties

Table (15): The arithmetic means and the standard deviations of the items related to Challenges and Difficulties in descending order according to the arithmetic means

\begin{tabular}{|c|c|c|c|c|c|}
\hline Rank & No & Area & Arithmetical mean & $\begin{array}{l}\text { Standard } \\
\text { deviation }\end{array}$ & Level \\
\hline 1 & 62 & $\begin{array}{l}\text { Teachers suffer from the low level of } \\
\text { knowledge about quality culture } \\
\text { standards. }\end{array}$ & 3.82 & 1.188 & Medium \\
\hline 2 & 59 & $\begin{array}{l}\text { The implementation of the quality } \\
\text { management methodology requires a } \\
\text { big time and effort. }\end{array}$ & 3.52 & .974 & Medium \\
\hline 3 & 60 & $\begin{array}{l}\text { The school environment does not } \\
\text { provide the necessary requirements for } \\
\text { applying the quality management } \\
\text { methodology. }\end{array}$ & 3.50 & 1.097 & Medium \\
\hline 4 & 61 & $\begin{array}{l}\text { Teachers resist the application of } \\
\text { quality management as a new } \\
\text { management method for developing a } \\
\text { culture of quality. }\end{array}$ & 3.49 & 1.233 & Medium \\
\hline 5 & 58 & $\begin{array}{l}\text { The teachers do not have sufficient } \\
\text { skills and knowledge to apply the } \\
\text { quality management methodology. }\end{array}$ & 3.23 & .992 & Medium \\
\hline 6 & 57 & $\begin{array}{l}\text { The principal is concerned with the } \\
\text { lack of resources: financial and human } \\
\text { to apply the quality management } \\
\text { methodology. }\end{array}$ & 3.05 & 1.017 & Medium \\
\hline & & Challenges and Difficulties & 3.44 & .819 & Medium \\
\hline
\end{tabular}

Table (15) shows that the arithmetic means ranged (3.05-3.82), as item (62) states that" Teachers suffer from the 
low level of knowledge about quality culture standards", came in the first rank with a mean of (2.32), while item (57), which states, "The principal is concerned with the lack of resources: financial and human to apply the quality management methodology", came in the last rank, with a mean of (3.05). The arithmetic mean of Challenges and Difficulties as a whole was (3.44).

The results of the study indicated that implementing Hoshin Kanri methodology in developing quality of culture at the Jordanian secondary schools was medium. This result can be explained by the fact that Jordanian schools do not have a clear vision about the nature of this methodology and the practices it contains for applying it on the ground in its organizational processes. It can also be said that the degree of implementing was medium because there are clear discrepancies between the Hoshin Kanri methodology and the practices of total quality management adopted by the majority of Jordanian schools because they are in line with the educational philosophy in the Jordanian educational system, as this system calls for the adoption of best practices for the development of quality education given to students.

\section{Recommendations}

In light of the results, the study recommends the following:

- Developing instruments aimed at developing the level of effective implementation of the Hoshin Kanri methodology in Jordanian schools.

- Holding courses aimed at introducing secondary school principals and teachers about Hoshin Kanri methodology and its role in promoting a culture of quality.

- Conducting more studies related to the aspired methodology and its impact on a group of other educational and administrative variables.

\section{References}

10.1 References in English

Ahmad, H. (2016). A proposed systematic framework for applying Hoshin Kanri strategic planning methodology in educational institutions. European Scientific Journal, 12(16), 158-194.

Alic, A. \& Ideskog, J. (2016). Hoshin Kanri-the Japanese of piloting. Unpublished Master Thesis, Jonkoping University, Sweden.

Avila, L. (2018). Total quality management (TQM) practices of school administrators in relation to school performance among teacher education institutions in the province of Quezon. $4^{\text {th }}$ International Research Conference of Higher Education, 23-26 January 2018, Bali, Indonesia.

Dziminska, M., Fijallkowska, J. \& Sulzowski, L. (2018). Trust-based quality culture conceptual model for higher education institutions. Sustainability, 10, 1-22.

Melander, A., Lofving, M., Andersson, D., Elgh, F. \& Thulin, M. (2016). Introduction to Hoshin Kanri strategic management system in manufacturing SMEs. Management Decision, 54(10), 2507-2523.

Nicholas, J. (2014). Hoshin Kanri and critical success factors in quality management and lean production. Total Quality Management and Business Excellence, 27(4), 250-269.

Osada, H. (1998). Strategic management by policy in total quality management. Strategic Change, 7, 277-287.

Sharon, W. (2017). Tentatively exploring the learning potentialities of postgraduate distance learners, interaction with other people in their life context: Distance. Education, 34(1), 175-188.

Souad, D., Messaouda, C. \& Maazouzi, K. (2017). Planning using Hoshin Kanri. International Journal of Academic Research in Economics and Management Sciences, 6 (4), 1-13.

Souad, D., Messaouda, C. \& Maazouzi, K. (2017). Planning using Hoshin Kanri. International Journal of Academic Research in Economics and Management Sciences, 6 (4), 1-13.

Witcher, B. (2014). Hoshin Kanri through the eyes of English language texts. Perspectives on Performance, 11(1), 16-24.

\subsection{References in Arabic}

Al-Baddah, Ahmed and Al-Sarayrah, Khaled. (2012). Proposed Vision to Develop Dtandards for Quality Management and Guarantee in Jordanian Universities in the Light of e-Learning Techniques. 
The Arab Journal of Quality Assurance in University Education, 1 (9) 181-209.

Gohar, Salah al-Din. (2017), Introduction to Education Management and Organization, Cairo: Ain Shams Library.

Al-Khudair, Khudair bin Saud. (2001). Indicators of Quality of Higher Education Outcomes in the Countries of the Cooperation Council for the Arab States of the Gulf: an Analytical Study. Cooperation Journal. The Cooperation Council for the Arab States of the Gulf, 16 (53), 13-132. 